\title{
DOTS for temporary workers in the agricultural sector. An exploratory study in Tuberculosis case detection
}

M Clarke, M Cur, Faculty of Applied Sciences, Cape Technikon \& Department of Public Health Sciences, Division of International Health (IHCAR), Karilinska Institutet, Stockholm, Sweden.

J Dick, PhD, The Medical Research Council, Health Systems Research Unit, Tygerberg.

M Zwarenstein, MB ChB, The Medical Research Council, Health Systems Research Unit, Tygerberg

V Diwan, MB ChB, PhD, Department of Public Health Sciences, Division of International Health (IHCAR), Karilinska Institutet, Stockholm, Sweden.

\section{Abstract}

\section{Key words}

Agriculture, Farm labour, Farm worker, Point prevalence, South Africa, Tuberculosis, Temporary farm workers,

\section{Introduction}

This study was conducted in the Boland health district of the Cape Winelands of South Africa where there is a high tuberculosis incidence and prevalence. A survey conducted on 211 farms in the study district during 1998 , reported that $65 \%(n=9042)$ of all workers on these farms, were temporarily employed. Temporary farm workers live in communities either within or on the outskirts of the boundaries of the Boland health district, from where they are transported to work daily.

\section{Research objective}

To estimate the point prevalence of sputum smear-positive tuberculosis among temporary farm workers in the Boland health district, and to determine whether temporary farm workers diagnosed with tuberculosis, have access to anti-tuberculosis treatment.

\section{Study design}

The study took the form of a cross-sectional active case finding survey amongst adult temporary farm workers (not living on farms) on the four study farms in the Boland health district.

\section{Results}

Data was analysed using the Epi Info Version 6 computer programme. Four (4) existing (self-reported) tuberculosis cases were identified and six (6) previously undiagnosed new sputum smear-positive cases of tuberculosis were detected. The total point prevalence was 10 cases of tuberculosis in the cohort of temporary farm workers, resulting in a point prevalence rate of 2809 cases per 100000 temporary farm workers $(95 \% \mathrm{CI} 1090$ -4527 ). If the four (4) self-reported cases of tuberculosis are excluded in the calculation, the point prevalence of new sputum smear-positive tuberculosis cases is six (6) and the prevalence rate 1685 cases per (95\% CI 468 - 2909). Of the four self-reported tuberculosis cases, one indicated that their supply of medication was depleted, whereas the other three indicated that they had the required treatment at home.

\section{Discussion}

Tuberculosis is a major health problem in this region of South Africa and the incidence is projected to increase in correlation with the increasing prevalence of HIV/ AIDS. Recent legislative changes in South Africa have resulted in a trend where farmers decrease their permanent work force and increase their use of a temporary work force. The nature of temporary employment in the agricultural industry creates potential difficulties for farm workers to access tuberculosis health care. The early detection and effective case management of this high-risk group presents a special challenge to the South African health community. 


\section{Abstrak Inleiding}

Hierdie studie was onderneem in die hoë tuberkulose insidensie en prevalensie Bolandse gesondheidsdistrik. geleë is in die Kaapse wynland van Suid Afrika. 'n Ondersoek wat op 211 plase onderneem was in 1998, het gevind dat $65 \%(n=9042)$ van al die plaaswerkers wie indiens was op hierdie plase, was tydelike in diens geneem. Tydelike plaaswerkers is woonagtig in gemeenskappe in en buite die grense van die Boland gesondheidsdistrik, vanwaar hul daagliks vervoer word na die plaas waar hul werk.

\section{Doel van navorsing}

Om die tydstip prevalensie van smeer positiewe tuberkulose onder tydelike volwasse plaaswerkers in die Wes-Kaap, Suid Afrika te bepaal, en om vas te stel of die gediagoseerde tuberkulose gevalle toegang het tot anti-tuberkulose behandeling.

\section{Studie ontwerp}

'n Kruisseksionele aktiewe tuberkulose gevalle ondersoek was onderneem om die gevalle op te spoor onder die tydelike volwasse plaaswerkers (nie woonagtig op die plaas), werksaam op die vier studie plase in die Bolandse gesondheidsdistrik.

\section{Resultate}

Die data was geanaliseer deur gebruik te maak van die EPI Info Version 6 rekenaar program. Daar was vier (4) gediagnoseerde tuberkulose (self gerapporteer) gevalle en ses (6) ongediagnoseerde nuwe sputum smeer positiewe tuberkulose gevalle ge-identifiseer. Die totale tuberkulose tydstip prevalensie was 10 gevalle onder die tydelike plaas werkers; bereken word as 'n prevalensie koers van 2809 gevalle per 100000 tydelike plaas werkers of te wel ' $\mathrm{n} 95 \%$ Vertrouens Interval van I 090-4527 gevalle per 100000 tydelike plaas werkers. Sou die vier (4) self gerapporteerde gevalle by hierdie berekening uitgelaat word, dan word die tydstip prevalensie ses (6) gevalle, met 'n prevalensie koers vir nuwe smeer positiewe tuberkulose van 1685 gevalle per 100000 tydelike plaas werkers, met ' $n$ Vertrouens Interval van 468 - 2909 per 100000 tydelike plaas werkers.

Een van die vier self aangemelde tuberkulose gevalle het aangedui dat haar/sy voorraad van medikasie uitgeput was, waar drie van die vier aangedui dat hul voldoende voorraad beskik, en dat dit by hul huis is.

\section{Bespreking}

Tuberkulose is ' $\mathrm{n}$ prominente gesondheids probleem in hierdie streek van Suid Afrika, met 'n geprojekteerde verhoging van die tuberkulose prevalensie in samehang met die toename van MIV/VIGS. Wetlike veranderinge in Suid Afrika het gelei tot "n die neiging dat landbou produsente hul permanente werkersmag verklein het, teenoor ' $n$ toename van die seisoenale- en tydelike werkersmag. Die indiensneming van tydelike plaaswerkers in die landbou, lei tot potensiele probleme vir diesulkes om toegang te verkry tot tuberkulose gesondheidssorg. Die vroeë opsporing en effektiewe bestuur van hierdie hoë risiko groep, bied besondere uitdagings vir die Suid Afrikaanse gesonheids gemeenskap.

\section{Introduction}

The Western Cape is an agricultural region supporting a fruit and wine industry. Current legislation attempts to transform labour relations in the commercial agricultural sector to improve legal protection of the labour force.

These Acts include the Basic Conditions of Employment Act No.75 of 1997, Employment Equity Act No. 55 of 1998, Skills Development Act No. 97 of 1998, Labour Relations Act no. 66 of 1995 and Occupational Health and Safety Act No.85 of 1993. Unexpectedly, these legislative changes have acted as a disincentive for farm owners to employ permanent staff. Permanent farm workers living on the farms now have the legal right to demand land tenure (Restructuring of Land Rights Act No. 22 of 1994). Consequently the number of temporary farm workers is increasing at double the rate of permanent workers (Van Rooyen, Groenewald, Ngqangweni and Fenyes 1998:1-17 and South African Department of Labour 2001).

The pattern of temporary employment of farm workers together with their low wages, limited access to education, transport and employment activities makes them a potentially high-risk group for contracting tuberculosis. Very limited information is available about the health needs of, and the utilization of health services by temporary farm workers
(Theron, 2002). Health managers in the Boland health district have requested information on the prevalence of tuberculosis in this group as well as their access to tuberculosis services.

Tuberculosis remains a major public health problem in the Western Cape Region of South Africa where it was declared a provincial emergency in 1997 (World health Organization 1999:60).

An upsurge in incidence is projected with the rising prevalence of HIV/AIDS, despite efforts to implement the comprehensive World Health Organization strategy of Directly Observed Treatment Short (DOTS) course (Grange 1999: 9 -11 ).

The DOTS strategy includes an ensured supply of antituberculosis drugs, effective monitoring utilizing standardised registers, clear definitions of the tuberculosis type and treatment outcomes (Department of Health, 1996: ii). A steady increase has been observed in the prevalence rate of the pulmonary tuberculosis cases reported in the Western Cape province and the Boland health district alike, in 1998-2000. See Table 1.

This paper describes the results of a rapid appraisal undertaken to estimate the number of known and unknown sputum smear-positive (infectious) tuberculosis cases prevalent amongst temporary farm workers at work. This survey 
Table 1: Prevalence rate of reported pulmonary tuberculosis per 100000 population

\begin{tabular}{|l|l|l|l|}
\hline AREA & $\mathbf{1 9 9 8}$ & $\mathbf{1 9 9 9}$ & $\mathbf{2 0 0 0}$ \\
\hline *Western Cape Province & 518 & 546 & 585 \\
\hline *Boland Health District & 1109 & 1155 & 1180 \\
\hline Temporary farm workers & Not available & Not available & 2809 \\
\hline
\end{tabular}

*Source: Department of Health, Western Cape Province. June 2002 the logistics of the survey, the four largest farms that were included in the 211-farm survey from the district, were selected for the study (Schoeman \& Van Zyl, 2000). At the time of the study, 244 permanent farm workers lived permanently on these four farms and up to 1110 temporary farm workers were employed during the peak season (Schoeman \& Van Zyl, 2000). The selection of these farms created a bias in the was done prior to a large-scale implementation of a lay health worker programme designed to improve tuberculosis case finding and case holding on farms in the Boland health district.

\section{Materials and method Research objectives}

To establish the point prevalence (Beaglehole, Bonita and Kjellstrom 1993:14) of sputum smear-positive tuberculosis cases on the day of the study, among the temporary farm workers working on the largest four farms in the study area of the Boland health district, and to categorize them as:

\footnotetext{
- Diagnosed and receiving treatment, and

- Undiagnosed.
}

\section{Ethical Approval}

The Cape Technikon Interim Ethical Committee and the Ethical Committee for Research of the Karolinska Institutet, Stockholm reviewed this study for ethical approval. Both these committees granted ethical approval.

\section{Study setting}

The study was conducted in the labour intensive agricultural area of the Boland health district, situated about 65 kilometers northeast from Cape Town. The population of the district was estimated at 70000 people in 2000 (Boland District Municipality, 2001). The well-developed agricultural infrastructure produces wine and fruit for export. The permanently employed farm workers lived on the farms where they were employed, with their families in closed micro-communities. Farmers transport temporary farm workers between their homes and the farms daily.

The Boland health district introduced the DOTS strategy during mid 1997. Clinics are open to the public between $09 \mathrm{H} 00$ and $15 \mathrm{H} 30$ on weekdays. Sputum test results are posted to clients, but the contact details provided by the individuals concerned are invariably incorrect and consequently the clinic now requests that the individual return for the result one week after the test was taken.

\section{Study population}

This descriptive, exploratory study was implemented at a time when the proportion of temporary to permanent workers was not known for the whole health district. To simplify study in all likelihood. This because large farms are more profitable, pay higher salaries, employ fewer temporary workers and offer better access to health care; thus the study sample is likely to underestimate the proportion of temporary workers and the prevalence of tuberculosis. The convenient random sampling method was used to finalise the study sample, using two inclusion criteria; (i) participants had to be temporary farm employees at work on any of the four study farms on the specific day, and (ii) were not living on the farm.

\section{Questionnaire}

A questionnaire was designed and piloted in collaboration with health providers from the Boland health district. The questionnaire was structured to collect demographic information of the study participants and specific data associated with the process of active case finding for pulmonary tuberculosis, i.e. weight loss, persistent coughing for three weeks, chest pain, shortness of breath, and haemoptysis. The participants who reported two or more of these symptoms were requested to give permission to be referred for further testing, on site. The participants, who reported they had tuberculosis and were on treatment, were questioned in terms of their access to treatment and whether someone observes them taking it.

\section{Data collection}

Permission to access the farm properties was obtained in collaboration with the district health services. The process of active case finding was conducted on the 28 September 2000 using a team of eight trained, bilingual interviewers. All farm work sites were visited and all workers identified as temporary were asked permission for an interview. Participants were ensured that all information would remain confidential and were assured of their anonymity. Verbal, informed consent was obtained from each participant in the study. Participants were informed that they were at liberty to withdraw at any given time during the interview or refuse referral for further investigation.

The consenting participants, who indicated that they suffered from two or more of the tuberculosis related signs and symptoms, were referred to the on-site medical team, for sputum collection that was sent for bacteriological examination for tuberculosis. Volunteers from the local Rotary club assisted with the administrative control of the questionnaires and referrals made. 
Figure 1: TB signs and symptoms reported

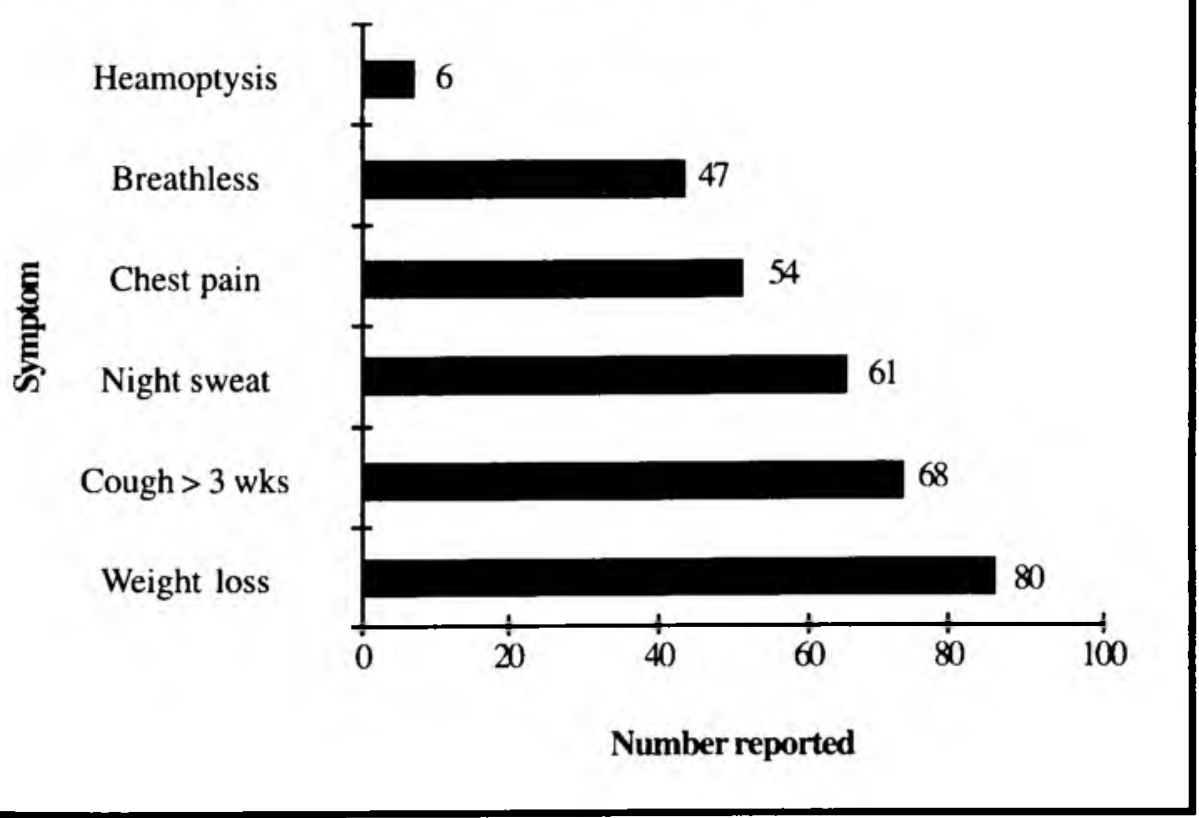

outside the Boland health district. In order to protect anonymity, nothing further was done with regard to these cases such confirming the type of tuberculosis and accuracy of their reports.

The tuberculosis point prevalence of the temporary farm workers (including the four self-reported cases) on the day of the study was 10 of the $356(2.8 \%)$. Of the 69 respondents investigated for tuberculosi, six ( $8.7 \%)$ participants were confirmed to be new sputum smear-positive, pulmonary (infectious) tuberculosis cases, by the laboratory.

Tuberculosis specific signs and symptoms reported by the cohort (356) are presented in Figure 1 . Seventy, $(22 \%)$ of the remaining 318 temporary farm

\section{Data management and statistical analysis}

Data was collected using questionnaires that were completed by the trained interviewers. The demographic data included sex, age, mother tongue, whether they lived on the farm or not, whether they intended to work only on the one farm or not, working for the whole season or part thereof and their family/personal history regarding tuberculosis. Data from the completed questionnaires were entered into Epi Info Version 6, and the point prevalence with $95 \%$ Confidence Intervals (CI) was calculated. Epi Info 6 is a multipurpose computer programme designed for epidemiological researchers and public health personnel.

\section{Results}

On the day of the study 422 temporary farm workers were employed on these four farms, of which 356 (84\%) complied with the inclusion criteria to form the study sample. Sixty-six (15.6\%) of the 422 temporarily employed farm workers were identified as family members of permanent farm workers (living on the farm) and were excluded from the analysis.

All 356 temporary farm workers included in the study lived in surrounding towns and were transported to work by the employer every day of the week. One hundred and two (29\%) of the cohort spoke Xhosa. The predominant language of the area was reported to be Afrikaans. Two hundred and eighty six (80\%) of the cohort was female, ranging from 16 to 60 years in age with a median of 29 years. Four of the respondents were unable to give their ages.

\section{Tuberculosis Prevalence}

Thirty-four $(9.6 \%)$ of the cohort reported previous tuberculosis treatment, while $1 \%(4 / 356)$ reported that they were currently on tuberculosis treatment from a health facility workers in the cohort (356 minus 34 previously treated for tuberculosis minus 4 current self- reported cases $=318$ ) had two or more symptoms suggestive of tuberculosis, and were referred for bacteriological investigations. One respondent ( 1 of the 70 ) refused this referral.

Of the participants who reported they were taking tuberculosis treatment, one indicated that their supply of medication was depleted and the other three indicated that they took the required treatment at home. All cases indicated that they were taking their treatment without the supervision of another person. Three of the reported tuberculosis cases indicated that they send family members to collect their treatment from the clinic within their communities. One of the participants who reported to be on tuberculosis treatment, indicated that someone who worked at the local clinic dropped the treatment off at the home of the participant.

\section{Discussion}

If the four (4) self-reported tuberculosis cases are included in the calculation, the study indicates a tuberculosis point prevalence of 10 cases. The point prevalence rate was calculated $(\mathrm{P} \pm 1.96 \mathrm{vP}[1-\mathrm{P}] / \mathrm{N})$ at $2809 / 100000$ temporary farm workers (95\% CI $1090-4527$ ) working in the Boland health district. This is nearly five (4.8) times higher than the estimated tuberculosis prevalence rate of the Western Cape province and twice (2.4 times) as high as the estimated prevalence rate for that health district, during 2000 (Boland District Municipality, 2001 Department of Health PAWC, 2001). See Table 1. If the four (4) self reported cases are excluded then the point prevalence is six (6) cases of new sputum smear-positive tuberculosis and the prevalence rate is 1685 cases per 100000 temporary farm workers with a 95\% Cl 468 to 2909 per 100000 temporary farm workers for the new sputum smear-positive tuberculosis cases, which is still above the district rate. Other research has found that temporary farm workers are a group at high risk of contracting tuberculosis and that this disease is an occupational 
problem for farm workers (Center of Disease control 1992: 1- 13 and Ciesielski et al. 1991: 1715 - 1719).

The success of tuberculosis control depends on two essential functions, early detection, followed by effective treatment of infectious patients to ensure a cure (Dye 2000: S146-S152). Temporary farm workers lead a life of relative poverty, working long hours with little access to health care facilities either on the job or at their homes that are often far from the farms on which they work. Health services have responded with mobile services on farms but currently have a strategy aimed at centralising services and reducing the number of individual farms visited by the mobile clinics (Boland District Council, 2001). Temporary farm workers could not receive directly observed tuberculosis treatment at clinics near their homes during their period of employment, as they were far from home, working during the operational hours of the clinics. Employment may be arranged at short notice and can be sporadic; and even health care during periods of unemployment is not predictable and may be interrupted.

Continuity of care should be maintained by interventions in the workplace, in this instance on farms. By expanding the lay health worker intervention on farms in combination with: (i) increased mobile health services on to farms; (ii) health screening on arrival; and (iii) active communication between services at the workplace, at home and in the health district of work; DOTS continuity could be ensured for temporary farm workers.

\section{Conclusion}

Based on this study, it is concluded that the temporary farm worker community is at particular high risk of not having new sputum smear-positive tuberculosis cases detected and effectively treated at an early stage of the disease.

In addition, their hours of work far away from home, the unavailability of public transport and the 'no work, no pay' policy on many farms for temporary workers may contribute to delays in their health care seeking behaviour. These factors also make treatment management difficult and call for innovative solutions.

\section{Recommendation}

An ongoing strategy for the early detection and treatment of new sputum smear-positive tuberculosis cases and the management of the DOTS strategy in this high risk group be further investigated, towards formulating an appropriate approach to be adopted by the Public Health Sector in their local tuberculosis control programme.

A further study is recommended to determine whether the knowledge of tuberculosis influences the health seeking behaviour among temporary farm workers, which can otherwise lead to delays in accessing appropriate health care.

\section{Acknowledgements}

The researchers would like to thank Mrs Sandra Theron, Head of Health in the Boland health district as well as the Council and staff members of the Boland health district. We also extend our thanks to Mrs Hendrien van $\mathrm{Zyl}, \mathrm{Mr}$
Albany Frolick, Ms Myrtle Williams, Mrs Marlise Morkel; the farmers that allowed us access their properties; the participants of the interviews; Mr Hennie Schoeman for capturing the data and the Drakenstein Rotary Club members. The Medical Research Council funded the research.

\section{References}

BEAGLEHOLE, R; BONITA, R \& KJELLSTRÖM,T 1993: Basic Epidemiology. Geneva: world Health Organization.

CIESIELSKI,SD; SEED,JR; ESPOSITO,DH; \& HUNTER, N 1991: The Epidemiology of Tuberculosis among North Carolina Migrant Farm Workers. JAMA. 1991; 265(13): Pp 1715-1719.

CENTER FOR DISEASE CONTROL 1992: Prevention and Control of Tuberculosis in Migrant Farm Workers Recommendations of the Advisory Council for the Elimination of Tuberculosis. MMWR, 1992; 41(RR10): 1- 13.

DEPARTMENT OF HEALTH, SOUTH AFRICA 199: The South African TB Control Programme. Practical guidelines. Pretoria: Government Printers.

DEPARTMENT OF HEALTH, PROVINCIAL ADMINISTRATION WESTERN CAPE JUNE 2002: Request for TB Information. Cape Town: Department of Health.

DYE, C 2000: Tuberculosis 2000 - 2010: control, but not elimination. Int J Tuberc Lung Dis. 2000; 4(12): S146-S152.

GRANGE, JM 1999: The global burden of tuberculosis. (In: Porter, JDH \& Grange, JM. Eds. 1999: Tuberculosis - an interdisciplinary perspective. London: Imperial College: Pp 3-32.)

KIRONDE, S; BAMFORD, L. 2002: Tuberculosis. South African Health Review 2002. Chapter 9. Durban: Health Systems Trust.

SCHOEMAN, HJ \& VAN ZYL, CH 2000: Wellington Farm LHW Project Baseline - 1998 and Randomisation Report. Parow: Medical Research Council. Unpublished.

SOUTH AFRICAN DEPARTMENT OF LABOUR 2001: Determination of the employment conditions in South African agriculture: An investigation into minimum wages and conditions of employment for the agricultural sector.

SOUTH AFRICA (REPUBLIC) 1997: Basic Conditions of Employment Act No.75. Pretoria: Government Printer.

SOUTH AFRICA (REPUBLIC) 1998: Employment Equity Act No. 55. Pretoria: Government Printer.

SOUTH AFRICA (REPUBLIC) 1998: Skills Development Act No. 97. Pretoria: Government Printer.

SOUTH AFRICA (REPUBLIC) 1995: Labour Relations Act No. 66. Pretoria: Government Printer. 
SOUTH AFRICA (REPUBLIC) 1993: Occupational Health and Safety Act No.85. Pretoria: Government Printer.

SOUTH AFRICA (REPUBLIC) 1994: Restructuring of Land Rights Act No.22. Pretoria: Government Printer.

THERON 2002: Interview on 22 May 2002 Interview in terms of the health needs of the temporary farm worker community.

VAN ROOYEN,J; GROENEWALD, J: NGQANGWENI,S \& FENYES, T 1998: Agricultural policy reform in South Africa. Cape Town: AIPA / Francolin.

WORLD HEALTH ORGANIZATION 1999: Status of Tuberculosis in the 22 High-Burden Countries. WHO/CDS/ TB/99.271. 